\title{
Cationic carboxamide derivatives of tricyclic heteroaromatic compounds: synthesis and preliminary evaluation of antiproliferative activity
}

\author{
Valentina G. Kostina, Inna V. Alexeeva, Nadia A. Lysenko, Valentina V. Negrutska, Igor Y. Dubey* \\ Institute of Molecular Biology and Genetics of the NAS of Ukraine, 150 Zabolotnogo St., Kyiv, 03680, Ukraine
}

\begin{abstract}
This research was aimed at the synthesis and study of biological activity of the carboxamides of tricyclic heteroaromatic systems, acridone, phenazine, and thioxanthone, containing the aliphatic and aromatic cationic substituents at amide fragment. These heterocyclic cores are DNA intercalating agents, whereas the introduction of cationic groups provides additional ionic interactions of the ligands with their biological targets, such as DNA and enzymatic complexes of the system of nucleic acids biosynthesis. A convenient way of the introduction of such groups is a modification of heterocyclic carboxamides. A small library of new $N$-substituted cationic amide derivatives of acridone-4-, phenazine-1- and thioxanthone-4-carboxylic acids was obtained. They were synthesized in 37-81\% yield by mild and selective quaternization of the nitrogen atoms at $N, N$-dimethylaminoalkyl (alkyl = ethyl, propyl) and pyridylmethyl fragments of the neutral $N$-functionalized carboxamides with methyl iodide. Tricyclic heteroaromatic cores were not affected. Convenient protocol for the synthesis of thioxanthone-4-carboxylic acid (TCA) based on the reaction of 2-mercaptobenzoic and 2-iodobenzoic acids followed by cyclization of the intermediate was developed (yield 79\%). A series of new $N$-functionalized neutral amides of TCA, the precursors of corresponding cationic carboxamide, were also obtained via the reaction of acyl chloride with amines. Preliminary in vitro testing of four compounds as potential antitumor agents in U87MG tumor cell culture (human malignant glioma) demonstrated their significant antiproliferative activity at low micromolar concentrations, with growth inhibition values $\mathrm{GI}_{50}$ in the range $1.7-11 \mu \mathrm{M}$. These results suggest that cationic carboxamides of tricyclic heteroaromatic systems are promising scaffolds for the design of new antitumor drugs.
\end{abstract}

Keywords: acridone; phenazine; thioxanthone; carboxamides; antitumor agents.

\section{Introduction}

Condensed tricyclic heteroaromatic systems are privileged scaffolds for the design of therapeutic agents for the treatment of various diseases [1-5]. In particular, a broad variety of antitumor, antibacterial, and antiviral drugs belong to this class of compounds, including the derivatives of acridine, phenazine, and thioxanthone. In most cases, such compounds target the cellular enzymatic systems of nucleic acids biosynthesis. Small molecules based on condensed tricyclic heterocycles were reported as efficient

\begin{tabular}{ll}
\hline Received: & 20.05 .2020 \\
Revised: & 29.05 .2020 \\
Accepted: & 12.06 .2020 \\
Published online: & 30.06 .2020 \\
\hline
\end{tabular}

* Corresponding author. Tel.: +380-44-200-0379;

e-mail: dubey@imbg.org.ua (I. Y. Dubey)

ORCID: 0000-0003-4023-4293 inhibitors of a number of enzymes involved in nucleic acids metabolism, including e.g. DNA and RNA polymerases [6], topoisomerases [7-19], and telomerase [20-25].

The majority of non-nucleoside inhibitors of the enzymes of nucleic acid biosynthesis are based on heteroaromatic polycyclic scaffolds. Their effect is usually associated with interaction with DNA (duplex and quadruplex structures) via intercalation or groove binding, or with DNA-enzyme complexes [26-31]. It should be noted that the planar aromatic systems of acridines and acridones, phenazines, thioxanthones, and similar molecules allow efficient intercalation into DNA via the $\pi$ - $\pi$-stacking with electronic systems of nucleic base pairs $[11,12,32,33]$.

Easily available functionalized tricyclic heteroaromatic carboxamides containing $N$-alkyl and $N$-aryl substituents have been extensively studied as potential anticancer, antibacterial, and antiviral drugs [8-10, 16, 18, 20, 24]. Important factors influencing their biological activity are

(C) Kostina V. G. et al. This is an open-access article distributed under the terms of the Creative Commons Attribution License, which permits unrestricted use, distribution, and reproduction in any medium, provided the original author and source are credited. 
Important factors influencing their biological activity are the structure of heterocycle, the nature of amide substituent, and the position of the carboxamide group in the core molecule $[10,16]$.

Biological activity of carboxamide derivatives of acridine and phenazine has been investigated for several decades. Carboxamides containing the $\mathrm{NHCH}_{2} \mathrm{CH}_{2} \mathrm{NMe}_{2}$ pharmacophore, such as $\mathrm{N}$-[2-(dimethylamino)-ethyl] carboxamide derivatives of phenazine [34], acridine (DACA) [8] and 9-aminoacridine [35] were identified as efficient antitumor agents and topoisomerase inhibitors. $\mathrm{N}$-arylamides of acridone-4-carboxylic acid are active against hepatitis $\mathrm{C}$ virus infection inhibiting the transcription and RNA replication [36]. $N$-pyridyl derivatives of acridone carboxamides were found to inhibit NS3 helicase [36, 37], telomerase [24], and topoisomerase I [38]. $N$-aryl(hetaryl)-substituted amides of phenazine-1carboxylic acid appeared to be efficient antimicrobial agents, including the compounds active against drugresistant Mycobacterium tuberculosis strains [39, 40].

Much less attention has been paid to the studies of bioactivity of compounds based on thioxanthone, a close acridone analogue. Among thioxanthone derivatives, antitumor agents have been reported [41-43], although we were unable to find have not found in the literature data on the activity of thioxanthone carboxamides.

We have previously obtained a series of carboxamides of acridone and phenazine whose amide groups were functionalized with $N, N$-dimethylaminoalkyl and pyridyl fragments [38]. The introduced basic functions can be protonated under physiological conditions to form cationic moieties. Structure design was based on the fact that the attachment of basic/cationic substituents to DNA-intercalating ligands could enhance their binding to DNA or enzymatic complexes formed by the enzymes of nucleic acids biosynthesis (topoisomerase, telomerase, DNA, and RNA polymerases, etc.) by additional interactions with either anionic DNA phosphates or acidic groups within the enzymes. At the same time, the aromatic pyridyl residues could also interact with nucleic acids bases or aromatic amino acids via the hydrophobic mechanism further enhancing the binding of ligands to their molecular targets. Phenazine and acridone derivatives containing aromatic pyridyl fragments were found to inhibit the topoisomerase I at $100 \mu \mathrm{M}$ concentration, whereas their analogues with aliphatic basic substituents at carboxamide fragment were less efficient [38]. At the same time, the free core heterocycles and their non-substituted carboxamides are inactive against topoisomerase [38] and telomerase [24].

Thus, the introduction of protonable basic substituents significantly increased the biological activity of tricyclic carboxamides, and we could expect that the modification of core heterocycles with cationic fragments would result in even more efficient inhibitors with potential antitumor and/or antibacterial properties. In this work, we have significantly extended the range of $\mathrm{N}$-substituted tricyclic carboxamides as potential antitumor agents.

\section{Results and discussion}

Before we have synthesized a set of neutral carboxamide derivatives of acridone 1a-e and phenazine 2a-e

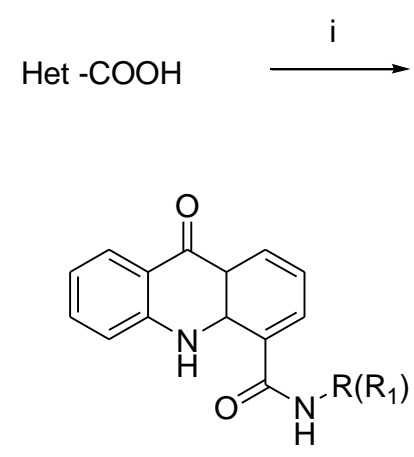

1

R:<smiles>CCCN(C)C</smiles>

a<smiles>CCCC[N+](C)(C)C</smiles>

f<smiles>CCCCCCCC(=O)N[R17](=O)c1cccc2nc3ccccc3nc12</smiles>

2

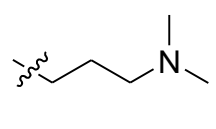

b<smiles>CCCC[N+](C)(C)C</smiles>

g<smiles>CCc1ccccn1</smiles>

C<smiles>CCc1cccc[n+]1C</smiles>

h<smiles>[R17][R]NC(=O)C1=CC=CC2C(=O)c3ccccc3SC12</smiles>

3<smiles>CCCc1cccnc1</smiles><smiles>CCCc1ccncc1</smiles>

d<smiles>CCCc1ccc[n+](C)c1</smiles><smiles></smiles>

j

Scheme 1. Synthesis of neutral (a-e) and cationic (f-j) derivatives of tricyclic carboxamides. (i). $\mathrm{SOCl}_{2}$, toluene, $\mathrm{Py}, \Delta$; (ii). R-NH , triethylamine, rt; (iii) methyl iodide, $\mathrm{MeOH}$ or $\mathrm{CH}_{3} \mathrm{CN}, 20-50{ }^{\circ} \mathrm{C}, 37-81 \%$. 


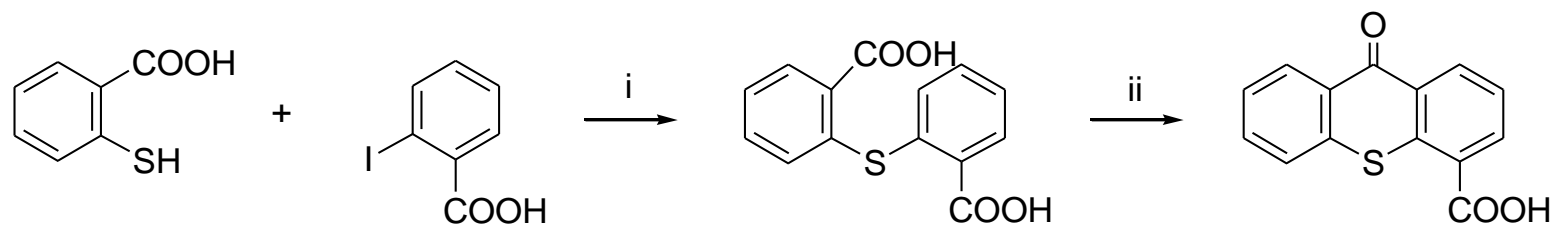

Scheme 2. Synthesis of thioxanthone-4-carboxylic acid. (i). $\mathrm{K}_{2} \mathrm{CO}_{3}$, DMF, $60{ }^{\circ} \mathrm{C}, 4 \mathrm{~h}$; (ii). conc. $\mathrm{H}_{2} \mathrm{SO}_{4}, 100{ }^{\circ} \mathrm{C}, 2.5-3 \mathrm{~h}, 79 \%$.

(Scheme 1). Their amide groups were functionalized with $\mathrm{N}, \mathrm{N}$-dimethylamino and isomeric pyridyl groups attached via the short (1-3 carbon atoms) alkyl linkers [38]. Taking into account the above considerations, we have decided to prepare cationic derivatives of tricyclic heterocycles. One of the possible ways to obtain compounds of this type would be a quaternization of nitrogen atoms of basic aliphatic and aromatic substituents present in the already prepared carboxamides 1,2a-e. We have also decided to extend the range of tricyclic heteroaromatic systems by adding their structural analogue, thioxanthone.

Carboxamides 1,2a-e have been previously synthesized from carboxylic acids [38]. To obtain analogues based on thioxanthone, first of all, we have elaborated an efficient procedure for the synthesis of thioxanthone-4-carbocylic acid (TCA). This procedure is similar to that commonly used for the synthesis of acridone-4-carboxylic acid [44] and is based on intramolecular cyclization of bis-dicarboxyphenyl sulfide formed in the reaction of 2-mercaptobenzoic and 2-iodobenzoic acids.

We have modified a published protocol [45] using potassium carbonate as a base instead of $\mathrm{NaOH}$, and 2-iodobenzoic acid in place of 2-chlorobenzoic acid. The condensation of two acids at $60^{\circ} \mathrm{C}$ followed by the intermediate cyclization by heating in conc. sulfuric acid afforded TCA in $79 \%$ yield (Scheme 2). The use of less reactive bromobenzoic acid in the condensation required heating at a higher temperature $\left(100^{\circ} \mathrm{C}\right)$ and resulted in a significantly lower total yield of target tricyclic carboxylic acid (below 50\%).

The synthesis of new $N$-substituted carboxamides of thioxanthone was based on our previous approach developed for phenazine and acridone series [38]. This convenient one-flask process consisted in the formation of acyl chloride followed by its reaction with amine. Target neutral amides 3a-e were obtained by the reaction of TCA chloride with corresponding amines in the presence of TEA (Scheme 1).

The neutral compounds 1-3a-e were found to easily react with methyl iodide, and the quaternization of nitrogen atoms in amide substituents allowed obtaining a series of novel cationic derivatives $\mathbf{1 - 3 f - j}$. $N$-Alkylation reaction was carried out in polar solvent (methanol, acetonitrile) at room temperature or with some heating (up to $50{ }^{\circ} \mathrm{C}$ ). Since salttype products precipitated from the reaction mixture, the use of crude amides instead of analytically pure samples did not significantly affect the total yield of iodides from starting carboxylic acids.
The primary centres of $N$-methylation are obviously tertiary aliphatic $\left(\mathrm{AlkNMe}_{2}\right)$ and pyridine nitrogen atoms in carboxamide fragments. Only one additional methyl group signal appeared in ${ }^{1} \mathrm{H}$ NMR spectra of all cationic derivatives. It is known that the quaternization of phenazine under the applied conditions does not occur, but possible alkylation of endocyclic nitrogen or exocyclic oxygen atom of the acridone ring could not be excluded. However, NMR spectra of the obtained derivatives and their comparison with the spectral data of reference compounds confirmed that compounds $\mathbf{1 f}$-j do not contain $N$-methyl group located at acridine ring, as one-proton low-field signals at $\delta \geq 12$ ppm characteristic of the 10-NH ring proton of neutral carboxamides of acridone carboxylic acid [44] are observed in the spectra. NMR spectra of cationic TCA carboxamides also contain the signals of methyl groups only from trimethylammonium or $\mathrm{N}$-methylpyridinium residues.

Cationic aliphatic trimethylammonium group of compounds 1-3f-g is represented by singlets at 3.1-3.4 ppm, whereas the spectra of pyridinium derivatives $\mathbf{1 h}-\mathbf{j}, \mathbf{2} \mathbf{i}$, and $\mathbf{3 i}$ contain the signals of cationic $N$-methyl group located at 4.2-4.4 ppm. Low-field shift of signals of the cationic fragments is observed in NMR spectra of the salts, as compared to corresponding neutral carboxamides. In general, the deshielding effect of cationic structures results in the shift of $\mathrm{CONH}$ and methylene protons (lowfield shift for $0.1-0.5$ and $0.15-0.25$ ppm, respectively) in comparison with neutral precursors.

Thus, we have prepared a series of 11 new compounds containing trimethylammonium group attached via the ethyl or propyl linker, and compounds with isomeric $N$-methylpyridinium fragments. This small library would allow analyzing the structure-activity relationship among the derivatives of three tricyclic systems - phenazine, acridone, and thioxanthone.

\section{Investigation of antitumor activity of compounds in vitro}

Preliminary evaluation of the antiproliferative activity of some new compounds was performed in vitro in the culture of U87MG tumor cells (human malignant glioma). To determine the effect of quaternization on biological activity, the representative pairs of the derivatives of two different heterocycles, acridone and phenazine, containing the same pyridyl and $N$-metyylpyridinium fragments (1d, i and $\mathbf{2 d}$, i) were tested. The cells were cultured in 24-well plates and treated for 3 days by drugs added at concentrations ranging from 20 to $0.5 \mu \mathrm{M}$. 
In vitro cytostatic activity of compounds towards cancer cell line was determined using the classic MTT assay [46]. MTT test is based on the transformation of MTT reagent (3-(4,5-dimethylthiazol-2-yl)-2,5-diphenyltetrazolium bromide) by the mitochondrial dehydrogenase of viable cells into the blue formazan which can then be measured spectrophotometrically. The optical density of the probe is proportional to the number of live cells. From the obtained data, the plots of the number of live cells in the probe as compared to a control (cell growth inhibition level) vs. drug concentration were built, from which the $\mathrm{GI}_{50}$ value was obtained for each tested carboxamide. $\mathrm{GI}_{50}$ was determined as a concentration of drug required for $50 \%$ of maximal inhibition of cell proliferation (decreasing cell vitality by $50 \%$ ) as compared to the non-treated control.

Tested carboxamides demonstrated a significant dosedependent antiproliferative activity towards U87MG cells at low micromolar concentrations, with $\mathrm{GI}_{50}$ below $10 \mu \mathrm{M}$ for three of four compounds (Table 1).

Table 1. Antiproliferative activity of compounds in the culture of U87MG cells $(\mathrm{M} \pm \mathrm{SD})$.

\begin{tabular}{ll}
\hline Compound & $\mathrm{GI}_{50}, \mu \mathrm{M}$ \\
\hline $\mathbf{1 d}$ & $11 \pm 2$ \\
$\mathbf{1 i}$ & $7.2 \pm 1.4$ \\
$\mathbf{2 d}$ & $1.7 \pm 0.3$ \\
$\mathbf{2 i}$ & $5.5 \pm 0.9$ \\
\hline
\end{tabular}

It is interesting to note that the cationic acridone derivative $\mathbf{1 i}\left(\mathrm{GI}_{50} 7.2 \mu \mathrm{M}\right)$ was more active than its neutral analogue 1d $\left(\mathrm{GI}_{50} 11 \mu \mathrm{M}\right)$, whereas for the pair of phenazine carboxamides the cationic compound $\mathbf{2 i}$ was three times less efficient as compared to its non-charged counterpart $2 \mathrm{~d}\left(\mathrm{GI}_{50} 5.5\right.$ and $1.7 \mu \mathrm{M}$, respectively).

The opposite effects of quaternization on the biological activity of acridone and phenazine carboxamides may be due to different molecular targets of the studied compounds and/or different modes of inhibitor-target interaction. However, at this moment we have only limited information on biological properties of a small set of derivatives, and molecular mechanisms of bioactivity of new compounds require further investigation. In particular, it will include the studies on the inhibition of the enzymes of nucleic acid biosynthesis and ligand interactions with nucleic acids. It would be also interesting to access the antibacterial activity of these derivatives.

\section{Conclusions}

A convenient protocol was proposed for the synthesis of cationic $N$-functionalized carboxamide derivatives of acridone, phenazine, and thioxanthone, the tricyclic systems with DNA-intercalating properties. A series of compounds with aliphatic and aromatic cationic substituents were obtained. Their heteroaromatic cores contained the carboxamide functions modified with
$N$-methylpyridiniumyl and $\mathrm{N}, \mathrm{N}, \mathrm{N}$-trimethylammonium groups. Preliminary evaluation of the antiproliferative activity of several compounds in tumor cell culture in vitro demonstrated that cationic tricyclic carboxamides could be suitable scaffolds for the development of new efficient antitumor agents.

\section{Experimental section}

Reagents and solvents for synthesis were purchased from UkrOrgSynthez (Ukraine), Fluka (Switzerland), and SigmaAldrich (Germany). Solvents were purified and dried by standard methods. DMSO for molecular biology and MTT reagent (3-(4,5-dimethylthiazol-2-yl)-2,5-diphenyltetrazolium bromide) were obtained from Sigma (USA). ${ }^{1} \mathrm{H}$ NMR spectra were recorded on a Mercury-400 instrument (400 MHz, Varian, USA) in DMSO-d 6 with tetramethylsilane as an internal standard; chemical shifts are given in ppm. Thin-layer chromatography (TLC) was performed on Silica gel $60 \mathrm{~F}_{254}$ plates (Merck, Germany) in following solvent systems: $\mathrm{CHCl}_{3} / \mathrm{MeOH}$ 9:1 (A); $\mathrm{CHCl}_{3} / \mathrm{MeOH}$ 1:1 (B); $\quad \mathrm{CHCl}_{3} / \mathrm{HOAc} /$ acetone $\quad 10: 0.125: 0.125 \quad$ (C); $i$ - $\mathrm{PrOH} / \mathrm{NH}_{4} \mathrm{OH} / \mathrm{H}_{2} \mathrm{O}$ 7:1:2 (D), $\mathrm{CHCl}_{3} / \mathrm{HOAc}$ acetone (E). Melting points were determined using a Boethius PNMK 05 apparatus (Nagema, Germany).

\section{Chemistry}

Acridone and phenazine carboxamide derivatives 1,2a-e were obtained as previously reported [38].

\section{9-Oxo-9H-thioxanthene-4-carboxylic acid (TCA).}

The mixture of 2-mercaptobenzoic acid (1.16 g, $7.53 \mathrm{mmol})$, 2-iodobenzoic acid (1.89 $\mathrm{g}, 7 \mathrm{mmol})$ and powdered $\mathrm{K}_{2} \mathrm{CO}_{3}(2.09 \mathrm{~g}, 15.2 \mathrm{mmol})$ in $10 \mathrm{ml}$ of dry DMF was stirred at $60{ }^{\circ} \mathrm{C}$ for $7.5 \mathrm{~h}$. After cooling, $60 \mathrm{ml}$ of water was added and insoluble material was filtered off. The filtrate was neutralized with $10 \% \mathrm{HCl}$, the precipitate was collected by filtration, washed with water and dried. The obtained crude 2-(2-carboxyphenylthio)benzoic acid (1.94 g) was kept in $7.5 \mathrm{ml}$ of conc. sulfuric acid for $2.5-3 \mathrm{~h}$ at $100{ }^{\circ} \mathrm{C}$ (control TLC in system E). The reaction mixture was cooled and poured into ice-cold water, and the precipitate was filtered and extensively washed with water. After its re-precipitation from $20 \mathrm{ml}$ of $10 \% \mathrm{NaOH}$ with $10 \% \mathrm{HCl}$ the crude product $(1.52 \mathrm{~g})$ was crystallized from DMF. Yield of yellow crystals $79 \%, \mathrm{mp} 332-335^{\circ} \mathrm{C}$. ${ }^{1} \mathrm{H}$ NMR (400 MHz, DMSO- $\left.d_{6}\right) \delta 8.78(\mathrm{~d}, 1 \mathrm{H}, J 8.0 \mathrm{~Hz}$, Ar), 8.49 (d, 1H, J 7.6 Hz, Ar), 8.43 (d, 1H, J 8.0 Hz, Ar), $7.92(\mathrm{~d}, 1 \mathrm{H}, J 8.0 \mathrm{~Hz}, \mathrm{Ar}), 7.81(\mathrm{t}, 1 \mathrm{H}, J 7.2 \mathrm{~Hz}, \mathrm{Ar}), 7.70$ (t, 1H, J 7.6 Hz, Ar), $7.61(\mathrm{t}, 1 \mathrm{H}, J 7.6 \mathrm{~Hz}, \mathrm{Ar})$.

General procedure for the synthesis of $N$-substituted amides of thioxanthone-4-carboxylic acid (3a-e).

$0.5 \mathrm{Mmol}(128 \mathrm{mg})$ of TCA was suspended in $3 \mathrm{ml}$ of dry toluene, and $50 \mu \mathrm{l}$ of thionyl chloride and $60 \mu \mathrm{l}$ of dry pyridine $(0.7 \mathrm{mmol}$ each) were added with stirring and the mixture was heated at $90{ }^{\circ} \mathrm{C}$ for $1.5-2 \mathrm{~h}$. After cooling to room temperature corresponding amine $(1.25 \mathrm{mmol})$ and triethylamine $(1.25 \mathrm{mmol})$ were added, and the mixture was 
stirred at ambient temperature until the reaction was complete (control TLC). The mixture was evaporated, the residue was treated with $10 \mathrm{ml}$ of chloroform and washed with saturated $\mathrm{NaHCO}_{3}(3 \times 5 \mathrm{ml})$. The organic phase was dried over $\mathrm{Na}_{2} \mathrm{SO}_{4}$ and evaporated to dryness. The product was crystallized from the appropriate solvent.

\section{9-Oxo-9H-thioxanthene-4-carboxylic acid} dimethylaminoethyl)-amide (3a)

was obtained from $146 \mathrm{mg}(0.57 \mathrm{mmol}) \mathrm{TCA}$ and $138 \mu \mathrm{l}$ (1.26 mmol) $\mathrm{N}, \mathrm{N}$-dimethylaminoethylene diamine. Yield 26\%, mp $160-163{ }^{\circ} \mathrm{C}$ (acetonitrile). ${ }^{1} \mathrm{H}$ NMR (400 MHz, DMSO- $\left.d_{6}\right) \delta 8.72$ (br t, $\left.1 \mathrm{H}, \mathrm{CONH}\right), 8.63(\mathrm{~d}, 1 \mathrm{H}, J 8.0 \mathrm{~Hz}$, Ar), 8.42 (dd, 1H, J 8.0 Hz, $0.8 \mathrm{~Hz}, \mathrm{Ar}$ ), 7.98 (d, 1H, J 6.4 $\mathrm{Hz}, \mathrm{Ar}), 7.85$ (m, 1H, Ar), 7.79 (t, 1H, J 7.6 Hz, Ar), 7.66 (t, 1H, J $8.4 \mathrm{~Hz}, \mathrm{Ar}), 7.58$ (t, 1H, J $7.6 \mathrm{~Hz}, \mathrm{Ar}), 3.44$ (m, $\left.2 \mathrm{H}, \mathrm{NHCH}_{2}\right), 2.40\left(\mathrm{t}, 2 \mathrm{H}, J 6.4 \mathrm{~Hz}, \mathrm{CH}_{2} \mathrm{~N}\right), 2.21(\mathrm{~s}, 6 \mathrm{H}$, $\mathrm{NMe}_{2}$ ).

9-Oxo-9H-thioxanthene-4-carboxylic acid (3-dimethylaminopropyl)-amide (3b)

was obtained from $128 \mathrm{mg}(0.5 \mathrm{mmol})$ of TCA and $120 \mu \mathrm{l}(1.25 \mathrm{mmol})$ of $N, N$-dimetylaminopropylene-1,3diamine. Yield $58 \mathrm{mg}$ (34\%), $\mathrm{mp} 162-165{ }^{\circ} \mathrm{C}$ (acetonitrile). ${ }^{1} \mathrm{H}$ NMR (400 MHz, DMSO- $d_{6}$ ) $\delta 8.80$ (br t, $1 \mathrm{H}, J 5.6 \mathrm{~Hz}$, CONH), 8.62 (dd, 1H, J $8.4 \mathrm{~Hz}, 1.2 \mathrm{~Hz}, \mathrm{Ar}$ ), 8.43 (dd, 1H, $J 8.0 \mathrm{~Hz}, 0.8 \mathrm{~Hz}, \mathrm{Ar}), 7.99$ (dd, 1H, J 7.4 Hz, $1.2 \mathrm{~Hz}, \mathrm{Ar})$, 7.88-7.84 (m, 1H, Ar), 7.80-7.76 (m, 1H, Ar), $7.66(\mathrm{t}, 1 \mathrm{H}$, $J 7.6 \mathrm{~Hz}, \mathrm{Ar}), 7.59(\mathrm{t}, 1 \mathrm{H}, J 7.6 \mathrm{~Hz}, \mathrm{Ar}), 3.35(\mathrm{~m}, 2 \mathrm{H}$, $\left.\mathrm{NHCH}_{2}\right), 2.34\left(\mathrm{t}, 2 \mathrm{H}, J 7.2 \mathrm{~Hz}, \mathrm{CH}_{2} \mathrm{~N}\right), 2.17$ (s, 6H, NMe 2 ), $1.70\left(\mathrm{t}, 2 \mathrm{H}, \mathrm{J} 7.2 \mathrm{~Hz}, \mathrm{CH}_{2}\right)$.

9-Oxo-9H-thioxanthene-4-carboxylic acid (pyridin-2ylmethyl)-amide (3c)

was obtained from $o$-aminomethylpyridine. Yield $19 \%$, mp 192-194 ${ }^{\circ} \mathrm{C}(\mathrm{EtOH}) .{ }^{1} \mathrm{H}$ NMR (400 MHz, DMSO- $\left.d_{6}\right) \delta$ 9.45 (t, 1H, J 6.0 Hz, CONH), 8.65 (dd, 1H, J 8.4 Hz, 1.2 $\mathrm{Hz}, \mathrm{Ar}$ ), 8.55 (d, 1H, J 4.8 Hz, Ar), 8.43 (dd, 1H, J $8.4 \mathrm{~Hz}$, $1.2 \mathrm{~Hz}, \mathrm{Ar}$ ), 8.16 (dd, 1H, J 7.6 Hz, $1.6 \mathrm{~Hz}, \mathrm{Ar}), 7.87-7.78$ $(\mathrm{m}, 3 \mathrm{H}, \mathrm{Ar}), 7.70(\mathrm{t}, 1 \mathrm{H}, J 7.6 \mathrm{~Hz}, \mathrm{Ar}), 7.59$ (dt, 1H, J 8.0 $\mathrm{Hz}, 1.2 \mathrm{~Hz}, \mathrm{Ar}), 7.43$ (d, 1H, J 7.6 Hz, Ar), 7.31 (dd, 1H, J 7.6 Hz, $6.8 \mathrm{~Hz}, \mathrm{Ar}), 4.57$ (d, 2H, J 6.0 Hz, $\mathrm{CH}_{2}$ ).

9-Oxo-9H-thioxanthene-4-carboxylic acid (pyridin-3-ylmethyl)-amide (3d)

was obtained from $207 \mathrm{mg}(0.81 \mathrm{mmol})$ of TCA and $147 \mu \mathrm{l}(1.45 \mathrm{mmol})$ of $m$-aminomethylpyridine. Yield 152 mg (54\%), mp 194-198 ${ }^{\circ} \mathrm{C}$ (acetonitrile/i-PrOH). ${ }^{1} \mathrm{H}$ NMR (400 MHz, DMSO-d $) \delta 9.41$ (br t, $1 \mathrm{H}, J 4.4 \mathrm{~Hz}, \mathrm{CONH}$ ), $8.65(\mathrm{~m}, 2 \mathrm{H}, \mathrm{Ar}), 8.51(\mathrm{~d}, 1 \mathrm{H}, J 3.2 \mathrm{~Hz}, \mathrm{Ar}), 8.43(\mathrm{~d}, 1 \mathrm{H}$, $J 6.4 \mathrm{~Hz}, \mathrm{Ar}), 8.11$ (d, 1H, J 6.0 Hz, Ar), 7.88-7.75 (m, 3H, Ar), 7.67 (t, 1H, J 6.4 Hz, Ar), $7.57(\mathrm{t}, 1 \mathrm{H}, J 6.0 \mathrm{~Hz}, \mathrm{Ar})$, 7.44-7.40 (m, 1H, Ar), 4.57 (d, 2H, J 4.8 Hz, $\mathrm{CH}_{2}$ ).

9-Oxo-9H-thioxanthene-4-carboxylic acid (pyridin-4ylmethyl)-amide (3e)

was obtained from $p$-aminomethylpyridine. Yield 30\%, mp 194-197 ${ }^{\circ} \mathrm{C}(\mathrm{EtOH}) .{ }^{1} \mathrm{H}$ NMR (400 MHz, DMSO- $\left.d_{6}\right) \delta$ 9.45 (t, 1H, J $6.0 \mathrm{~Hz}, \mathrm{CONH}), 8.66$ (dd, 1H, J 7.6 Hz, 1.2
$\mathrm{Hz}, \mathrm{Ar}), 8.55$ (m, 2H, Ar), 8.43 (dd, 1H, J $8.0 \mathrm{~Hz}, 0.8 \mathrm{~Hz}$, Ar), 8.15 (dd, 1H, J 7.6 Hz, 1.6 Hz, Ar), 7.88-7.85 (m, 1H, Ar), $7.78(\mathrm{dt}, 1 \mathrm{H}, J 7.6 \mathrm{~Hz}, 1.2 \mathrm{~Hz}, \mathrm{Ar}), 7.71(\mathrm{t}, 1 \mathrm{H}, J 7.6$ $\mathrm{Hz}, \mathrm{Ar}), 7.60$ (dt, $1 \mathrm{H}, J 7.6 \mathrm{~Hz}, 1.2 \mathrm{~Hz}, \mathrm{Ar}), 7.40$ (dd, 2H, $J 4.4 \mathrm{~Hz}, 1.6 \mathrm{~Hz}, \mathrm{Ar}), 4.57$ (d, 2H, J $6.0 \mathrm{~Hz}, \mathrm{CH}_{2}$ ).

General procedure for the quaternization of carboxamides.

Neutral heterocyclic $N$-substituted carboxamide 1-3a-e $(0.1 \mathrm{mmol})$ and $150 \mu \mathrm{l}$ of methyl iodide in $2 \mathrm{ml}$ of methanol or acetonitrile were kept at room temperature or with weak heating (up to $50{ }^{\circ} \mathrm{C}$ ) until the reaction was complete (control TLC). The precipitated product (1-3f-j) was collected by filtration and crystallized from the appropriate solvent.

Trimethyl-\{2-[(9-oxo-9,10-dihydroacridine-4-carbonyl)amino]-ethyl\}-ammonium iodide (1f).

Yield 75\%, mp 260-263 ${ }^{\circ} \mathrm{C}(\mathrm{EtOH}) .{ }^{1} \mathrm{H}$ NMR (400 MHz, DMSO- $\left.d_{6}\right) \delta 12.26(\mathrm{~s}, 1 \mathrm{H}, \mathrm{NH}(\mathrm{Ar})), 9.28$ (br t, $1 \mathrm{H}$, CONH), 8.48 (d, 1H, J 7.6 Hz, Ar), 8.24 (m, 2H, Ar), 7.78$7.70(\mathrm{~m}, 2 \mathrm{H}, \mathrm{Ar}), 7.40(\mathrm{t}, 1 \mathrm{H}, J 7.6 \mathrm{~Hz}, \mathrm{Ar}), 7.34(\mathrm{t}, 1 \mathrm{H}$, J 7.2 Hz, Ar), $3.80\left(\mathrm{~m}, 2 \mathrm{H}, \mathrm{NHCH}_{2}\right), 3.61$ (br t, $\left.2 \mathrm{H}, \mathrm{CH}_{2} \mathrm{~N}\right)$, $3.19\left(\mathrm{~s}, 9 \mathrm{H}, \mathrm{N}^{+} \mathrm{Me}_{3}\right)$.

Trimethyl-\{3-[(9-oxo-9,10-dihydroacridine-4-carbonyl)amino]-propyl\}-ammonium iodide (1g).

Yield 64\%, mp 262-264 ${ }^{\circ} \mathrm{C}$ (acetonitrile). ${ }^{1} \mathrm{H}$ NMR (400 $\left.\mathrm{MHz}, \mathrm{DMSO}-d_{6}\right) \delta 12.40$ (s, 1H, NH (Ar)), 9.10 (br t, 1H, CONH), 8.46 (d, 1H, J 8.0 Hz, Ar), 8.27 (m, 1H, Ar), 7.797.71 (m, 2H, Ar), 7.39-7.31 (m, 2H, Ar), 3.45-3.39 (m, 4H, $\mathrm{NHCH}_{2}, \mathrm{CH}_{2} \mathrm{~N}$ ), 3.19 (s, 9H, N+Me $), 2.05$ (br t, $2 \mathrm{H}, \mathrm{CH}_{2}$ ).

1-Methyl-2-\{[(9-oxo-9,10-dihydroacridine-4-carbonyl)amino]-methyl\}-pyridinium iodide (1h).

Yield 37\%, mp 269-273 ${ }^{\circ} \mathrm{C}(\mathrm{DMF}) .{ }^{1} \mathrm{H}$ NMR (400 MHz, DMSO- $\left.d_{6}\right) \delta 12.10(\mathrm{~s}, 1 \mathrm{H}, \mathrm{NH}(\mathrm{Ar})), 9.86(\mathrm{t}, 1 \mathrm{H}, J 4.8 \mathrm{~Hz}$, CONH), 9.06 (d, 1H, J 4.8 Hz, Ar), 8.58-8.52 (m, 2H, Ar), 8.44 (d, 1H, J 7.6 Hz, Ar), 8.24 (d, 1H, J 8.4 Hz, Ar), 8.17 (d, 1H, J $8.4 \mathrm{~Hz}, \mathrm{Ar}), 8.06$ (m, 1H, Ar), 7.78-7.74 (m, 1H, Ar), 7.68 (d, 1H, J $8.4 \mathrm{~Hz}, \mathrm{Ar}), 7.43(\mathrm{~m}, 1 \mathrm{H}, \mathrm{Hz}, \mathrm{Ar}), 7.32$ (m, 1H, Ar), 5.0 (d, 2H, J 4.8 Hz, $\left.\mathrm{CH}_{2}\right), 4.44$ (s, 3H, N $\left.{ }^{+} \mathrm{Me}\right)$.

1-Methyl-3-\{[(9-oxo-9,10-dihydroacridine-4-carbonyl)amino]-methyl\}-pyridinium iodide $(\mathbf{1 i})$.

Yield 75\%, mp 240-244 ${ }^{\circ} \mathrm{C}$ (acetonitrile). ${ }^{1} \mathrm{H}$ NMR (400 $\left.\mathrm{MHz}, \mathrm{DMSO}-d_{6}\right) \delta 12.27$ (s, 1H, NH (Ar)), 9.73 (br t, 1H, $\mathrm{CONH}), 9.06(\mathrm{~s}, 1 \mathrm{H}, \mathrm{Ar}), 8.92(\mathrm{~s}, 1 \mathrm{H}, \mathrm{Ar}), 8.61(\mathrm{~d}, 1 \mathrm{H}$, $J 8.8 \mathrm{~Hz}, \mathrm{Ar}$ ), 8.50 (d, 1H, J 7.2 Hz, Ar), 8.39 (d, 1H, $J 8.4$ $\mathrm{Hz}, \mathrm{Ar}), 8.46$ (d,1H, J $8.4 \mathrm{~Hz}, \mathrm{Ar}), 8.13$ (s, 1H, Ar), 7.797.77 (m, 2H, Ar), 7.45-7.29 (m, 2H, Ar), 4.78 (d, 2H, J 5.6 $\left.\mathrm{Hz}, \mathrm{CH}_{2}\right), 4.37$ (s, 3H, N+Me).

1-Methyl-4-\{[(9-oxo-9,10-dihydroacridine-4-carbonyl)amino]-methyl\}-pyridinium iodide $(\mathbf{1 j})$.

Yield 66\%, mp 206-209 ${ }^{\circ} \mathrm{C}$ (acetonitrile). ${ }^{1} \mathrm{H}$ NMR (400 $\left.\mathrm{MHz}, \mathrm{DMSO}-d_{6}\right) \delta 12.29$ (br s, $1 \mathrm{H}, \mathrm{NH}(\mathrm{Ar})$ ), 9.83 (br s, $1 \mathrm{H}, \mathrm{CONH}), 8.95$ (m, 2H, Ar), 8.45-8.55 (m, 2H, Ar), 8.30- 
8.12 (m, 3H, Ar), 7.80-7.65 (m, 2H, Ar), 7.45-7.25 (m, 2H, Ar), 4.86 (br t, 2H, $\left.\mathrm{CH}_{2}\right), 4.31$ (s, 3H, N+Me).

Trimethyl-\{2-[(phenazine-1-carbonyl)-amino]-ethyl $\}$ ammonium iodide $(2 f)$.

Yield 42\%, mp 272-276 ${ }^{\circ} \mathrm{C}$ (EtOH/DMF). ${ }^{1} \mathrm{H}$ NMR (400 $\left.\mathrm{MHz}, \mathrm{DMSO}-d_{6}\right) \delta 10.55$ (br t, $\left.1 \mathrm{H}, \mathrm{CONH}\right), 8.67(\mathrm{~d}, 1 \mathrm{H}$, $J$ 7.2 Hz, Ar), 8.45-8.52 (m, 2H, Ar), 8.32 (d, 1H, J 8.0 Hz, Ar), 8.16-8.05 (m, 3H, Ar), 4.02 (d, 2H, J 6.0 Hz, NHCH ${ }_{2}$, 3.70 (br t, $2 \mathrm{H}, \mathrm{CH}_{2} \mathrm{~N}$ ), 3.25 (s, $9 \mathrm{H}, \mathrm{N}^{+} \mathrm{Me}_{3}$ ).

Trimethyl-\{3-[(phenazine-1-carbonyl)-amino]-propyl\}ammonium iodide $(\mathbf{2 g})$.

Yield $76 \%$, mp $277-280{ }^{\circ} \mathrm{C}$ (butanol/DMF). ${ }^{1} \mathrm{H}$ NMR (400 MHz, DMSO-d $) \delta 10.42(\mathrm{~s}, 1 \mathrm{H}, \mathrm{CONH}), 8.67(\mathrm{~d}, 1 \mathrm{H}$, $J 6.0 \mathrm{~Hz}, \mathrm{Ar}), 8.48$ (m, 2H, Ar), 8.32 (d, 1H, J 6.8 Hz, Ar), 8.14-8.01 (m, 3H, Ar), 3.62 (br s, 2H, $\mathrm{NHCH}_{2}$ ), 3.47 (br t, $2 \mathrm{H}, \mathrm{CH}_{2} \mathrm{~N}$ ), 2.17 (s, 9H, N+ $\mathrm{Me}_{3}$ ), 2.15 (br t, $2 \mathrm{H}, \mathrm{CH}_{2}$ ).

1-Methyl-3-\{[(phenazine-1-carbonyl)-amino]-methyl $\}$ pyridinium iodide $(2 \mathrm{i})$.

Yield $81 \%$, mp $236-238{ }^{\circ} \mathrm{C}$ (EtOAc). ${ }^{1} \mathrm{H}$ NMR (400 $\left.\mathrm{MHz}, \mathrm{DMSO}-d_{6}\right) \delta 10.94$ (br t, $\left.1 \mathrm{H}, \mathrm{CONH}\right), 9.11(\mathrm{~s}, 1 \mathrm{H}$, Ar), 8.92 (d, 1H, J 6.0 Hz, Ar), 8.73 (d, 1H, J $8.4 \mathrm{~Hz}, \mathrm{Ar})$, 8.66 (d, 1H, J $6.8 \mathrm{~Hz}, \mathrm{Ar}), 8.54$ (d, 1H, J 8.0 Hz, Ar), 8.48 (d, 1H, J $8.4 \mathrm{~Hz}, \mathrm{Ar}), 8.34$ (d, 1H, J 7.6 Hz, Ar), 8.19 (dd, 1H, J 7.2, 6.0 Hz, Ar), 8.12-8.02 (m, 3H, Ar), 4.97 (d, 2H, $\left.J 6.0 \mathrm{~Hz}, \mathrm{CH}_{2}\right), 4.37$ (s, 3H, $\left.\mathrm{N}^{+} \mathrm{Me}\right)$.

Trimethyl-\{2-[(9-oxo-9H-thioxanthene-4-carbonyl)amino]-ethyl\}-ammonium iodide (3f).

Yield 39\%, mp 267-270 ${ }^{\circ} \mathrm{C}$ (butanol/DMF). ${ }^{1} \mathrm{H}$ NMR (400 MHz, DMSO-d $) \delta 9.12$ (br.t, $1 \mathrm{H}, \mathrm{CONH}$ ), 8.67 (d, 1H, J 7.6 Hz, Ar), 8.44 (d, 1H, J 7.2 Hz, Ar), 8.06 (d, 1H, J 6.0 Hz, Ar), 7.85-7.78 (m, 2H, Ar), 7.73-7.69 (m, 1H, Ar), $7.61(\mathrm{~m}, 1 \mathrm{H}, \mathrm{Ar}), 3.75\left(\mathrm{~d}, 2 \mathrm{H}, J 6.0 \mathrm{~Hz}, \mathrm{NHCH}_{2}\right), 3.60$ (br t, $2 \mathrm{H}, \mathrm{CH}_{2} \mathrm{~N}$ ), 3.24 (s, $9 \mathrm{H}, \mathrm{N}^{+} \mathrm{Me}_{3}$ ).

Trimethyl-\{3-[(9-oxo-9H-thioxanthene-4-carbonyl)amino]-propyl\}-ammonium iodide $(\mathbf{3 g})$.

Yield 52\%, mp 263-265 ${ }^{\circ} \mathrm{C}(\mathrm{EtOH}) .{ }^{1} \mathrm{H}$ NMR (400 MHz, DMSO- $\left.d_{6}\right) \delta 8.90$ (br.s, $1 \mathrm{H}, \mathrm{CONH}$ ), 8.66 (br s, $1 \mathrm{H}, \mathrm{Ar}$ ), 8.43 (br s, 1H, Ar), 8.11 (br s, 1H, Ar), 7.85-7.60 (m, 4H, Ar), 3.52-3.33 (m, 4H, $\left.\mathrm{NHCH}_{2}, \mathrm{CH}_{2} \mathrm{~N}\right), 3.09$ (s, 9H, $\mathrm{N}^{+} \mathrm{Me}_{3}$ ), 2.05 (br t, $2 \mathrm{H}, \mathrm{CH}_{2}$ )

1-Methyl-3-\{[(9-oxo-9H-thioxanthene-4-carbonyl)amino]-methyl\}-pyridinium iodide (3i).

Yield $81 \%, \mathrm{mp} 228-231{ }^{\circ} \mathrm{C}(\mathrm{MeOH} / \mathrm{DMF}) .{ }^{1} \mathrm{H}$ NMR $\left(400 \mathrm{MHz}, \mathrm{DMSO}-d_{6}\right) \delta 9.57$ (br t, $\left.1 \mathrm{H}, \mathrm{CONH}\right), 9.06$ (s, $1 \mathrm{H}, \mathrm{Ar}), 8.93(\mathrm{~d}, 1 \mathrm{H}, J 5.6 \mathrm{~Hz}, \mathrm{Ar}), 8.68(\mathrm{~d}, 1 \mathrm{H}, J 8.0 \mathrm{~Hz}$, Ar), 8.61 (d, 1H, J $8.4 \mathrm{~Hz}, A r), 8.43$ (d, 1H, J $8.0 \mathrm{~Hz}, A r)$, 8.23 (d, 1H, J 7.6 Hz, Ar), $8.16(\mathrm{~m}, 1 \mathrm{H}, \mathrm{Ar}), 7.85-7.81$ (m, 2H, Ar), 7.73 (m, 1H, Ar), $7.62(\mathrm{~m}, 1 \mathrm{H}, \mathrm{Ar}), 4.73$ (d, 2H, J $\left.5.6 \mathrm{~Hz}, \mathrm{CH}_{2}\right), 4.39$ (s, 3H, N $\left.\mathrm{N}^{+} \mathrm{Me}\right)$.

\section{In vitro antitumor assay.}

Antiproliferative activity of compounds was evaluated in the culture of human malignant glioma cells (U87MG line).
The cells were grown in 24-well plastic plates (TTP, Switzerland) in $\mathrm{CO}_{2}$-incubator at $37{ }^{\circ} \mathrm{C}, 5 \% \mathrm{CO}_{2}$. The cells $\left(2 \times 10^{3}\right.$ per well $)$ were cultured in Dulbecco's modified Eagle's medium (DMEM, Sigma, USA) supplemented with $2.5 \%$ fetal bovine serum (Sigma, USA). In $24 \mathrm{~h}$ after cell seeding, tested compounds in DMSO were added to the culture at concentrations $20,10,5,2,1$ and $0.5 \mu \mathrm{M}$ (final drug concentration in the medium) using a serial dilution approach, and then cells were incubated for $72 \mathrm{~h}$. In all cases, DMSO content in the medium was $0.2 \%$. Preliminary experiments confirmed that DMSO at this concentration did not affect cell growth. The cells cultured in the presence of $0.2 \%$ DMSO without drugs were used as a control. After the incubation of cells with or without drugs, the number of viable cells in each well was determined using a standard MTT colorimetric assay [46]. After the treatment wit MTT reagent, optical density in the wells was measured at $570 \mathrm{~nm}$ using BioTek ELx800 plate reader (BioTek, USA). Using the absorbance measurements, the percent of growth inhibition as compared with a non-treated control was calculated for each drug concentration. Growth inhibition levels were plotted against inhibitor concentrations, and $\mathrm{GI}_{50}$ parameter (drug concentration giving a $50 \%$ growth inhibition in comparison with a control culture) was determined for each compound. Each experiment was performed in triplicate. The data are presented as the mean (M) \pm standard deviation (SD).

\section{Notes}

Acknowledgments. The authors are grateful to Dr. O. Balynska for assistance with biological testing of compounds.

\section{The authors declare no conflict of interest.}

Author contributions. V. G. K.: synthesis of compounds, investigation. I. V. A.: investigation, NMR spectra analysis, writing the experimental part (chemistry). N. A. L.: synthesis of compounds. V. V. N.: biological experiments, writing the experimental part (biology). I. Y. D.: supervision, data analysis, writing, and editing the manuscript.

\section{References}

1. Gensicka-Kowalewska, M.; Cholewiński, G.; Dzierzbicka, K. Recent developments in the synthesis and biological activity of acridine/acridone analogues. RSC Adv. 2017, 7, 15776-15804.

2. Prasher, P.; Sharma, M. Medicinal chemistry of acridine and its analogues. Medchemcomm. 2018, 9, 1589-1618.

3. Buus, J.; Nielsen, J. Phenazine natural products: biosynthesis, synthetic analogues, and biological activity. Chem. Rev. 2004, 104, 1663-1686.

4. Guttenberger, N.; Blankenfeldt, W.; Breinbauer, R. Recent developments in the isolation, biological function, biosynthesis, and synthesis of phenazine natural products. Bioorg. Med. Chem. 2017, 25, 6149-6166.

5. Paiva, A. M.; Pinto, M. N.; Sousa, F. A century of thioxanthones: through synthesis and biological applications. Curr. Med. Chem. 2013, 20, 2438-2457.

6. Piestrzeniewicz, M. K.; Wilmańska, D.; Studzian, K.; Szemraj, J.; Czyż, M.; Denny, W. A.; Gniazdowski, M. Inhibition of RNA synthesis in vitro by acridines - relation between structure and activity. Z. Naturforsch., C, J. Biosci. 1998, 53, 359-368. 
7. Rewcastle, G. W.; Atwell, G. J.; Chambers, D.; Baguley, B. C.; Denny, W. A. Potential antitumor agents. 46. Structure-activity relationships for acridine monosubstituted derivatives of the antitumor agent $\mathrm{N}$-[2-(dimethylamino)ethyl]-9-aminoacridine-4carboxamide. J. Med. Chem. 1986, 29, 472-477.

8. Atwell, G. J.; Rewcastle, G. W.; Baguley, B. C.; Denny, W. A. Potential antitumor agents. 50. In vivo solid-tumor activity of derivatives of $N$-[2-(dimethylamino)ethyl]acridine-4-carboxamide. $J$. Med. Chem. 1987, 30, 664-669.

9. Wakelin, L. P. G.; Adams, A.; Denny, W. A. Kinetic studies of the binding of acridine carboxamide topoisomerase poisons to DNA: implications for mode of binding of ligands with uncharged chromophores. J. Med. Chem. 2002, 45, 894-901.

10. Goodell, J. R.; Madhok, A. A.; Hiasa, H.; Ferguson, D. M. Synthesis and evaluation of acridine- and acridone-based anti-herpes agents with topoisomerase activity. Bioorg. Med. Chem. 2006, 14, 5467-5480.

11. Ferreira, R.; Aviño, A.; Mazzini, S.; Eritja, R. Synthesis, DNAbinding and antiproliferative properties of acridine and 5-methylacridine derivatives. Molecules 2012, 17, 7067-7082.

12. Lafayette, E. A.; Vitalino de Almeida, S. M. Synthesis, DNA binding and topoisomerase I inhibition activity of thiazacridine and imidazacridine derivatives. Molecules 2013, 18, 15035-15050.

13. Janočková, J.; Plšiková, J.; Kova', J.; Jendželovský, R.; Mikeš, J.; Kašpárková, J.; Brabec, V.; Hamulaková, S.; Fedoročko, P.; Kožurková, M. Tacrine derivatives as dual topoisomerase I and II catalytic inhibitors. Bioorg. Chem., 2015, 59, 168-176.

14. Krokidis, M. G.; Molphy, Z.; Efthimiadou, E. K.; Kokoli, M.; Argyri, S.-M.; Dousi, I.; Masi, A.; Papadopoulos, K.; Kellett, A.; Chatgilialoglu, C. Assessment of DNA topoisomerase I unwinding activity, radical scavenging capacity, and inhibition of breast cancer cell viability of $N$-alkyl-acridones and N,N'-dialkyl-9,9'biacridylidenes. Biomolecules 2019, 9, 177-191.

15. Nunhart, P.; Konko'ová, E.; Janovec, L.; Jendželovský, R.; Vargová, J.; Ševc, J.; Matejová, M.; Miltáková, B.; Fedoročko, P.; Kozurkova, M. Fluorinated 3,6,9-trisubstituted acridine derivatives as DNA interacting agents and topoisomerase inhibitors with A549 antiproliferative activity. Bioorg. Chem. 2020, 94, 103393.

16. Gamage, S. A.; Spicer, J. A.; Rewcastle, G. W.; Milton, J.; Sohal, S.; Dangerfield, W.; Mistry, P.; Vicker, N.; Charlton, P. A.; Denny, W. A. Structure-activity relationships for pyrido-, imidazo-, pyrazolo-, pyrazino- and pyrrolophenazine carboxamides as topoisomerasetargeted anticancer agents. J. Med. Chem. 2002, 45, 740-743.

17. Yang, P.; Yang, Q.; Qian, X.; Cui, J. Novel synthetic isoquinolino[5,4-ab]phenazines: Inhibition toward topoisomerase I, antitumor and DNA photo-cleaving activities. Bioorg. Med. Chem. 2005, 13, 5909-5914

18. Gamage, S. A.; Rewcastle, G. W.; Baguley, B. C.; Charlton, P. A.; Denny, W. A. Phenazine-1-carboxamides: Structure-cytotoxicity relationships for 9-substituents and changes in the H-boding pattern of the cationic side chain. Bioorg. Med. Chem. 2006, 16, 1160-1168.

19. Zhuo, S.-T.; Li, C.-Y.; Hu, M.-H.; Chen, S.-B.; Yao, P.-F.; Huang, S.-L.; Ou, T.-M.; Tan, J.-H.; An, L.-K.; Li, D.; Gu, L.-Q.; Huang, Z.-S. Synthesis and biological evaluation of benzo[a]phenazine derivatives as a dual inhibitor of topoisomerase I and II. Org. Biomol. Chem. 2013, 11, 3989-4005.

20. Cuenca, F.; Moore, M. J. B.; Johnson, K.; Guyen, B.; De Cian, A.; Neidle, S. Design, synthesis and evaluation of 4,5-di-substituted acridone ligands with high G-quadruplex affinity and selectivity, together with low toxicity to normal cells. Bioorg. Med. Chem. Lett. 2009, 19, 5109-5113.

21. Sparapani, S.; Haider, S. M.; Doria, F.; Gunaratnam, M.; Neidle, S. Rational design of acridine-based ligands with selectivity for human telomeric quadruplexes. J. Am. Chem. Soc. 2010, 132, 12263-12272.

22. Ungvarsky, J.; Plsikova, J.; Janovec, L.; Koval, J.; Mikes, J.; Mikesová, L.; Harvanova, D.; Fedorocko, P.; Kristian, P.; Kasparkova, J.; Brabec, V.; Vojtickova, M.; Sabolova, D.; Stramova, Z.; Rosocha, J.; Imrich, J.; Kozurkova, M. Novel trisubstituted acridines as human telomeric quadruplex binding ligands. Bioorg. Chem. 2014, 57, 13-29.

23. Gao, C.; Zhang, W.; He, S.; Li, S.; Liu, F.; Jiang, Y. Synthesis and antiproliferative activity of 2,7-diamino 10-(3,5-dimethoxy)benzyl$9(10 \mathrm{H})$-acridone derivatives as potent telomeric G-quadruplex DNA ligands. Bioorg. Chem. 2015, 60, 30-36.

24. Negrutska, V. V.; Saraieva, I. V.; Kostina, V. G.; Alexeeva, I. V.; Lysenko, N. A.; Dubey, I. Ya. Telomerase inhibition by new di- and trisubstituted acridine derivatives. Biopolym. Cell 2016, 32, 468-471.

25. Si, M. K.; Pramanik, S. K.; Ganguly, B. Tuning the ring strain effect in acridine derivatives on binding affinity with G-quadruplex-DNA:
A computational and experimental study. Int. J. Biol. Macromol. 2019, 124, 1177-1185.

26. Bischoff, G.; Hoffmann, S. DNA-binding of drugs used in medicinal therapies. Curr. Med. Chem. 2002, 9, 321-348.

27. Martinez, R.; Chacon-Garcia, L. The search of DNA-intercalators as antitumoral drugs: what it worked and what did not work. Curr. Med. Chem. 2005, 12, 127-151.

28. Pindur, U.; Jansen, M.; Lemster, T. Advances in DNA-ligands with groove binding, intercalating and/or alkylating activity: chemistry, DNA-binding and biology. Curr. Med. Chem. 2005, 12, 2805-2847.

29. Paul, A.; Bhattacharya, S. Chemistry and biology of DNA-binding small molecules. Curr. Sci. 2012, 102, 212-231.

30. Neidle, S. Quadruplex nucleic acids as novel therapeutic targets. $J$. Med. Chem. 2016, 59, 5987-6011.

31. Spiegel, J.; Adhikari, S.; Balasubramanian, S. The structure and function of DNA G-quadruplexes. Trends Chem. 2020, 2, 123-136.

32. Gatasheh, M.K.; Kannan, S.; Hemalatha, K.; Imrana, N. Proflavine an acridine DNA intercalating agent and strong antimicrobial possessing potential properties of carcinogen. Karbala Int. J. Mod. Sci. 2017, 3, 272-278.

33. Zozulya, V.; Blagoi, Yu.; Löber, G.; Voloshin, I.; Winter, S.; Makitruk, V.; Shalamay, A. Fluorescence and binding properties of phenazine derivatives in complexes with polynucleotides of various base composition and secondary structure. Biophys. Chem. 1997, 65, 55-63.

34. Cimmino, A.; Evidente, A.; Mathieu, V.; Andolfi, A.; Lefranc, F.; Kornienko, A.; Kiss, R. Phenazines and cancer. Nat. Prod. Rep. 2012, 29, 487-501

35. Atwell, G. J.; Cain, B. F.; Baguley, B. C.; Finlay, G. J.; Denny, W. A. Potential antitumor agents. Part 43. Synthesis and biological activity of dibasic 9-aminoacridine-4-carboxamides, a new class of antitumor agent. J. Med. Chem. 1984, 27, 1481-1486.

36. Stankiewicz-Drogon, A.; Palchykovska, L. G.; Kostina, V. G.; Alexeeva, I. V.; Shved, A. D.; Boguszewska-Chachulska, A. M. New acridone-4-carboxylic acid derivatives as potential inhibitors of Hepatitis $C$ virus infection. Bioorg. Med. Chem. 2008, 16, 8846-8852.

37. Stankiewicz-Drogon, A.; Dörner, B.; Erker, T.; BoguszewskaChachulska, A.M. Synthesis of new acridone derivatives, inhibitors of NS3 helicase, which efficiently and specifically inhibit subgenomic HCV replication. J. Med. Chem. 2010, 53, 3117-3126.

38. Kostina, V. G.; Alexeeva, I. V.; Lysenko, N. A.; Negrutska, V. V.; Dubey, I. Ya. Synthesis and biological evaluation of new derivatives of tricyclic heteroaromatic carboxamides as potential topoisomerase I inhibitors. Ukr. Bioorg. Acta. 2016, 14, 3-8.

39. Palchykovska, L. G.; Alexeeva, I. V.; Kostina, V. G.; Platonov, M. O.; Negrutska, V. V.; Deriabin, O. M.; Tarasov, O. A.; Shved, A. D New amides of phenazine-1-carboxylic acid: antimicrobial activity and structure-activity relationship. Ukr. Biokhim. Zh. 2008, 80, 140-147 (in Ukr.)

40. De Logu, A.; Palchykovska, L. H.; Kostina, V. H.; Sanna, A.; Meleddu, R.; Chisu, L.; Alexeeva, I. V.; Shved, A. D. Novel $N$-aryland $N$-heteryl phenazine-1-carboxamides as potential agents for the treatment of infections sustained by drug-resistand and multidrugresistand Mycobacterium tuberculosis. Int. J. Antimicrob. Agents 2009, 33, 223-229.

41. US Patent No 5380749. Thioxanthenone antitumor agents / Miller, T. C.; Collins, J. C.; Mattes, K. C.; Wentland, M. P.; Perni, R. B.; Corbett, T. H.; Guiles, J. W. Patent appl. No 8/216989 23.03.1994. Publ. 10.01.1995.

42. Palmeira, A.; Vasconcelos, M. H.; Paiva, A.; Fernandes, M. X.; Pinto, M.; Sousa, E. Dual inhibitors of P-glycoprotein and tumor cell growth: (re)discovering thioxanthones. Biochem. Pharmacol. 2012, $83,57-68$.

43. Lima, R. T.; Sousa, D.; Paiva, A. M.; Palmeira, A.; Barbosa, J.; Pedro, M.; Pinto, M. M.; Sousa, E.; Vasconcelos, M.H. Modulation of autophagy by a thioxanthone decreases the viability of melanoma cells. Molecules 2016, 21, 1343-1357.

44. Rewcastle, G. W.; Denny, W. A. The synthesis of substituted 9oxoacridan-4-carboxylic acids. Part 2. The use of 2-iodoisophthalic acid in the Jourdan-Ullmann reaction. Synthesis 1985, 1985, 217-220.

45. Zhu, X.; Yang, J.; Zhao, G.; Luo, X.; Zhang, Q.; Mao, G.; Nie, J. Synthesis and characterization of highly efficient thioxanthone-based macrophotoinitiator. Sci. J. Mater. Sci. 2012, 2, 1-8.

46. Carmichael, J.; DeGraff, W. G.; Gazdar, A. F.; Minna, J. D.; Mitchell, J. B. Evaluation of a tetrazolium-based semiautomated colorimetric assay: assessment of chemosensitivity testing. Cancer Res. 1987, 47, 936-942. 


\title{
Катіонні карбоксамідні похідні трициклічних гетероароматичних сполук: синтез та попередня оцінка антипроліферативної активності
}

\author{
В. Г. Костіна, І. В. Алексєєва, Н. А. Лисенко, В. В. Негруцька, І. Я. Дубей*
}

Інститут молекулярної біологї̈ і генетики НАН Украӥни, вул. Заболотного, 150, Київ, 03680, Украӥна

Резюме: Метою роботи був синтез і вивчення біологічної активності карбоксамідів трициклічних гетероароматичних систем акридону, феназ ину та тіоксантону, що містять катіонні замісники в амідній функції. Вказані гетероциклічні ядра є ДНК-інтеркаляторами, а введення в них катіонних груп може забезпечити додаткові йонні взаємодії лігандів з їхніми біологічними мішенями, зокрема, ДнК й ферментативними комплексами системи біосинтезу нуклеїнових кислот. Модифікацію вказаних гетероциклів такими групами зручно здійснювати через карбоксамідні похідні. Виходячи з цього, було отримано невелику бібліотеку $N$-заміщених аліфатичних і ароматичних катіонних похідних амідів акридон-4-, феназин-1та тіоксантон-4-карбонових кислот. Їх синтезували 3 виходом 37-81\% 3 використанням м'якої селективної реакції кватернізації йодистим метилом атомів азоту в $N, N$-диметиламіноалкільних (алкіл = етил, пропіл) і піридилметильних фрагментах нейтральних $N$-функціоналізованих карбоксамідів. При цьому трициклічні ядра не реагують. Розроблено зручний протокол синтезу тіоксантон-4-карбонової кислоти (ТСА), що грунтується на реакції 2-меркаптобензойної та 2-йодбензойної кислот із наступною циклізацією інтермедіату (вихід 79\%). Отримано також серію нових нейтральних $N$-функціоналізованих амідів ТСА, які є прекурсорами відповідних катіонних карбоксамідів, взаємодією їі хлорангідриду з амінами. Попередне тестування чотирьох карбоксамідів in vitro як потенційних протипухлинних засобів проводили в культурі клітин U87МG (злоякісна гліома людини). Сполуки виявили значну антипроліферативну активність у низьких мікромолярних концентраціях; їхні показники інгібування клітинного росту $\mathrm{GI}_{50}$ знаходяться в межах 1.7-11 мкМ. Отримані дані свідчать про те, що катіонні карбоксаміди трициклічних гетероароматичних систем $є$ перспективними скафолдами для дизайну нових протипухлинних препаратів.

Ключові слова: акридон; феназин; тіоксантон; карбоксаміди; протипухлинні засоби. 